\title{
Assessment of Community Knowledge, Attitude and Practice towards Rabies in Mersa Town, Amhara Regional State, Ethiopia
}

\author{
Jemal Gebeyaw ${ }^{1}$, Friat Kidanemariam ${ }^{1}$, Haben Fesseha ${ }^{2 *}$ \\ ${ }^{1}$ College of Veterinary Science, Mekelle University, P.O. Box: 2084, Mekelle, Ethiopia \\ ${ }^{2}$ School of Veterinary Medicine, Wolaita Sodo University, P.O. Box: 138, Wolaita Sodo, Ethiopia
}

*Corresponding Author: Haben Fesseha, School of Veterinary Medicine, Wolaita Sodo University, P.O. Box: 138, Wolaita Sodo, Ethiopia

\begin{abstract}
Rabies is a worldwide zoonotic disease caused by the lyssavirus and it causes an acute fatal encephalitis that affects all mammals. Therefore, this present study was conducted to assess the community knowledge, attitude and practice on rabies in Mersa town, Amhara region, Ethiopia. A cross-sectional study was conducted from January 2019 to March 2019 in Mersa town. A total of 138 respondents were randomly selected and interviewed using a semi-structured questionnaire to assess the public awareness and practices about the disease. Descriptive and inferential statistics were performed to describe the data. Based on the current assessment, the majority (83.33\%) of the respondents haven't heard about rabies. The majority of the respondents $(52.5 \%)$ replied that rabies can be prevented by vaccination but there were misperceptions on transmission and clinical signs of the disease. Out of 120 respondents, 42(35\%) of them use herbal extract and traditional medicine as treatment of rabies. Furthermore, most (60.83\%) of respondents let their dogs free in the environment. Also, only $20.83 \%$ of the respondents vaccinate their dogs regularly. Overall, respondents having higher education levels take immediate action when a person has bitten by a rabid animal and these are found statistically significant ( $p<0.008)$. Besides, mostly they kill a rabid animal and visit health centers soon after the bite and this was also significantly associated $(p<0.048)$ with the level of the education of the respondents. Accordingly, the study showed that there was a low level of awareness and perception regarding rabies in the study community. Therefore, creating awareness to the community through training and public education should be implemented.
\end{abstract}

Keywords: Knowledge; Mersa; Practices; Questionnaire; Rabie; Altitude.

\section{INTRODUCTION}

Rabies is a viral zoonosis and human infection usually occurs following a transdermal bite or scratch by an infected animal (World Health Organization, 2005). Rabies is an acute viral infection caused by a lyssavirus in the family Rhabdoviridae. All warm-blooded animals including human beings are susceptible to it. The clinical signs include sudden behavioral changes, hypersalivation, paralysis, hydrophobia and photophobia, restlessness, aggressiveness and biting inanimate objects (Kloos and Berhane, 2006). Rabies causes about 26,000 to 55,000 deaths worldwide per year, more than $95 \%$ of which occur in Asia and Africa (Lozano et al., 2012). Every year, more than 15 million people worldwide receive a post-exposure vaccination to prevent the disease-this is estimated to prevent hundreds of thousands of rabies deaths annually. Still, rabies is the 10th biggest cause of death due to infectious diseases worldwide (World Health Organization, 2014).

Rabies is endemic in developing countries of Africa and Asia. The disease causes heavy losses in human and livestock population in the endemic region. The annual cost of rabies in Africa and Asia was estimated at $\$ 583.5$ million most of which is due to the cost of Post Exposure Prophylaxis (PEP) (Digafe et al., 2015; Kang et al., 2007). In Africa, the highest recorded human death due to the disease for the year 1998 was reported from Ethiopia (Eshetu et al., 2012).

In Ethiopia, rabies remains to be one of the most feared highly endemic infectious diseases. The annual death due to rabies was estimated to be 10,000 which makes it to be one of the worst affected countries in the world (Zewdie et al., 2018). The presence of a high population of dogs with poor management contributes to the high endemicity of canine rabies in Ethiopia. In canine rabies endemic 
countries like Ethiopia, rabies has also significant economic importance by its effect on livestock and in Africa and Asia, the annual cost of livestock losses as a result of rabies is estimated to be $\$ 12.3$ million (Knobel et al., 2005). The magnitude of the problem is higher in big cities like Addis Ababa linked with the presence of a large population of stray dogs and associated factors (Yimer et al., 2012).

Poor public awareness towards rabies is considered as one of the bottlenecks for the prevention and control of the disease in Ethiopia (Awoke et al., 2015). Understanding communities' knowledge, attitude, and practice is crucial to plan and implement appropriate control measures. Hence, knowledge, attitude and practice surveys of community have been undertaken in Ethiopia mainly in and around urban areas. However, a community-based KAP study hasn't been carried out in Mersa town, yet. Hence, this paper aims to assess the community knowledge, attitude, and practice of rabies in Mersa town.

\section{Materials AND Methods}

\subsection{Study Area}

The study was conducted in Mersa which is found in Mersa town, Habru district, North Wollo of the Amhara Region in Ethiopia. It has a latitude and longitude of $11^{\circ} 40^{\prime} \mathrm{N}-39^{\circ} 39.5^{\prime} \mathrm{E}$, with an elevation of 1600 meters. The town is found $486.7 \mathrm{~km}$ from Addis Ababa and its one of the larger areas in the Habru district. Mersa is located along Ethiopian Highway and the livestock population is 313,348 (LFOM, 2013).

\subsection{Study Population}

The study population included individuals who were resident on Mersa town Habru district, with different Socio-demographic characteristics. Habru district has 32 kebeles and Mersa town is one of the kebele which have four peasant association namely 01, 02, 03 and 04 . This study includes individuals of both sex, different age categories and occupation, different marital status and those which were found on different educational levels by simple random sampling. Besides, the target populations were interviewed with specific questions related to assessment, Knowledge, Attitude, and Practice of the community regarding rabies.

\subsection{Study Design}

A questionnaire survey was conducted using a semi-structured questionnaire by face to face interview to 138 randomly selected respondents to assess the public awareness and practices about the disease. However, the data collected from eighteen (18) respondents were found to be incomplete and excluded from the analysis. The questionnaire was designed to collect information about the respondents' knowledge of the disease, treatment and prevention practices as well as household information.

\subsection{Sample Size Determination}

Sample size was determined using Cochran's sample size formula for categorical data (Bartlett, 2001)

$$
n=Z^{2} \frac{p(1-p)}{e^{2}}
$$

Where, $Z=95 \%$ degree of confidence (1.96)

$\mathrm{P}=$ population proportion of target population, $\mathrm{Q}=1-\mathrm{p}$

$\mathrm{d}=$ degree of accuracy required

$\mathrm{n}=$ the sample size

$\mathrm{e}=$ allowable error

$\mathrm{p}=0.1=\underline{2650}$

$$
24000 \text { (household head of Habru district) }
$$

$\mathrm{q}=0.9$ where $\mathrm{P}=$ Household heads proportion of peasant association 01, 02, 03 and 04 Mersa town

$$
\mathrm{n}=1.96^{2} \underline{0.1^{*} 0.9}=138
$$


Assessment of Community Knowledge, Attitude and Practice towards Rabies in Mersa Town, Amhara Regional State, Ethiopia

\subsection{Sampling Technique}

The study was carried out face-to-face interviews using structured and pretest questionnaires which was primary data. The questionnaires were including items regarding their level of KAP concerning rabies management and control, household information, and pet care.

\subsection{Method of Data Collection}

The following general characteristics of a target population were included in the survey: gender, age, educational attainment and pet ownership for interviews which was primary data at selected households.

\subsection{Data Management and Analysis}

The data collected from the questionnaire survey were entered into Microsoft Excel 2016 spreadsheet and analyzed using STATA software version 13. Accordingly, descriptive statistics such as frequency distribution and percentages were used to summarize the findings. P-value less than 0.05 was considered as statistically significant.

\section{Results}

\subsection{Socio-Demographic Status of Respondents}

The study included more men (75\%) than women (25\%), and about (31.67\%) are illiterate who don't take any of education before. About (46.67\%) were between 30-40 years of age which the most productive age. Most of the respondents were reported to be living with pet $(52.2 \%)$ rather than other living without pets. Besides, the majority (42.5\%) of the family size was (4-6). Regards the occupation, merchants $(18.33 \%)$ were the most respondents followed by unemployment and farmers (Table1).

Table1. Sociodemographic characteristics of respondents in the Mersa town $(N=120)$.

\begin{tabular}{|l|l|l|}
\hline \multicolumn{1}{|c|}{ Variables } & \multicolumn{1}{|c|}{ Frequency } & \multicolumn{1}{c|}{ Percentage (\%) } \\
\hline Sex & & 75 \\
\hline Male & 90 & 25 \\
\hline Fge & 30 & \\
\hline Between 15-29 years & & 23.33 \\
\hline Between 30-40years & 28 & 46.67 \\
\hline Between 41-49 & 58 & 15 \\
\hline Between 50-60 & 18 & 10.8 \\
\hline$>60$ years old & 13 & 4.17 \\
\hline Education & 5 & \\
\hline Illiterate & & 31.67 \\
\hline Informal & 38 & 19.17 \\
\hline Primary school & 23 & 20.8 \\
\hline Secondary school & 25 & 11.67 \\
\hline Higher education & 14 & 16.67 \\
\hline Family size & 20 & \\
\hline 1-3 & & 41.67 \\
\hline 4-6 & 50 & 42.5 \\
\hline$>6$ & 51 & 15.83 \\
\hline Occupation & 19 & \\
\hline Government & & 11.67 \\
\hline Unemployment & 14 & 25.83 \\
\hline Farmer & 31 & 33.33 \\
\hline Merchant & 40 & 18.33 \\
\hline Housewife & 22 & 8.33 \\
\hline Others & 10 & 2.5 \\
\hline Living with pet & 3 & \\
\hline With pet & & 52.5 \\
\hline Without pet & 63 & 47.5 \\
\hline & 57 & \\
\hline & & \\
\hline & & \\
\hline & & \\
\hline & & \\
\hline & & \\
\hline
\end{tabular}


Assessment of Community Knowledge, Attitude and Practice towards Rabies in Mersa Town, Amhara Regional State, Ethiopia

\subsection{Knowledge of the Respondents on Rabies Disease}

The majority of respondents $(83.33 \%)$ in the study site had not heard about rabies whereas, $(16.67 \%)$ know about rabies. Besides, the Respondents were known the disease can be prevented by vaccination $(52.5 \%)$ even though $79.17 \%$ of respondents don't take any training about rabies disease. Out of 120 respondents $55 \%$ of the respondents know about the most common source of rabies for animals were dogs. With regards, the transmission majority $(35.3 \%)$ of the respondents described starvation and thirst as causes of the rabies disease and (30\%) respondents who know the disease mentioned bite and saliva as a means of transmission, while $(28.33 \%)$ of the precipitants perceived any type of contact (irrespective of the skin condition) with the saliva of the rabid individual as the source of infection. (43.33\%) of interviewers said that the sign of rabid animals was Sudden change in behavior whereas, $(36 \%)$ the respondents have claimed salivation (Table 2).

Table2. Knowledge of respondents regarding rabies disease in Mersa town

\begin{tabular}{|c|c|c|}
\hline $\begin{array}{r}\text { Variables } \\
\end{array}$ & Frequency & Percentage \% \\
\hline \multicolumn{3}{|l|}{ Ever heard rabies before } \\
\hline Yes & 100 & 83.33 \\
\hline No & 20 & 16.67 \\
\hline \multicolumn{3}{|l|}{ The cause of rabies } \\
\hline Virus & 31 & 25.83 \\
\hline Starvation and trust & 43 & 35.3 \\
\hline psychological problem & 11 & 9.17 \\
\hline Bacteria & 19 & 15.8 \\
\hline Protozoa & 0 & 0 \\
\hline I don't know & 16 & 13.33 \\
\hline \multicolumn{3}{|l|}{ Species affected by rabies } \\
\hline Dog only & 30 & 25.0 \\
\hline Dog and human & 51 & 42.5 \\
\hline Human and other domestic animals & 35 & 29.17 \\
\hline Domestic animals & 4 & 3.33 \\
\hline \multicolumn{3}{|l|}{ Means of transmission of rabies } \\
\hline Bite only & 35 & 29.17 \\
\hline Contact with Saliva only & 34 & 28.33 \\
\hline Bite and saliva & 36 & 30 \\
\hline Consumption of rabid animal meat & 3.5 & 2 \\
\hline Inhalation & 9 & 7.5 \\
\hline I don't know & 3 & 2.5 \\
\hline \multicolumn{3}{|c|}{ Animal species Transmit rabies to human } \\
\hline Dog only & 73 & 60.83 \\
\hline Dog and cat & 20 & 16.67 \\
\hline Other domestic animals & 27 & 22.5 \\
\hline \multicolumn{3}{|l|}{ Source of rabies } \\
\hline Dog & 66 & 55 \\
\hline Bovine & 1 & 0.83 \\
\hline Dog and cat & 29 & 24.17 \\
\hline Equine & 0 & 0 \\
\hline Dog and wild candies & 24 & 20 \\
\hline \multicolumn{3}{|l|}{ Sign of the disease } \\
\hline Salivation & 48 & 40 \\
\hline Sudden change in behavior & 52 & 43.33 \\
\hline All & 20 & 16.67 \\
\hline \multicolumn{3}{|l|}{ Is rabies fatal } \\
\hline Yes & 82 & 68.33 \\
\hline No & 17 & 14.17 \\
\hline I don't know & 21 & 17.5 \\
\hline \multicolumn{3}{|l|}{ Training for rabies } \\
\hline Yes & 25 & 20.83 \\
\hline No & 95 & 79.17 \\
\hline
\end{tabular}


Assessment of Community Knowledge, Attitude and Practice towards Rabies in Mersa Town, Amhara Regional State, Ethiopia

\begin{tabular}{|l|l|l|}
\hline Prevented by vaccination & & \\
\hline Yes & 63 & 52.5 \\
\hline No & 36 & 30 \\
\hline I don't know & 21 & 17.5 \\
\hline Total & 120 & 100 \\
\hline
\end{tabular}

\subsection{Attitude and Practice of the Respondents towards Rabies in Mersa Town}

According to table 3,63(52.5\%) of respondents kill the animal after being rabid. The study showed that only $27.5 \%$ of respondents for those peoples exposed to rabies used post-exposure vaccination. Conversely, 58(48.33\%) of interviewers not used post-exposure vaccination and sought traditional methods of treatment which employs the use of herbs (35\%) for immediate action for bitten man by a rabid animal. $20.83 \%$ of the respondents vaccinate their dogs. $61(50.83 \%)$ of interviewers said that the availability of vaccination in different clinics was sometimes, but, $(79.17 \%)$ of them not state the presence of dog vaccination and $(60.83 \%)$ of respondents were managing their dogs by kept let free. In general, higher education level was significantly associated with activities of the rabid animal $(\mathrm{x} 2=20.8480, \mathrm{p}<0.008)$ and immediate action taken for bitten man by a rabid animal $(\mathrm{x} 2=26.4728$, $\mathrm{p}<0.048$ ) with high score in killing and visit health center respectively (table 4).

Table3. Attitude and Practice of the Respondents towards Rabies

\begin{tabular}{|l|l|l|}
\hline \multicolumn{1}{|c|}{ Variables } & Frequency & Percentage \% \\
\hline Action for rabid animal & & \\
\hline Tie & 53 & 44.17 \\
\hline Killing & 63 & 52.5 \\
\hline Do nothing & 4 & 3.33 \\
\hline Immediate action taken for bitten man by rabid animal & & \\
\hline Visit health center & 56 & 46.67 \\
\hline Apply herbal extract & 42 & 35 \\
\hline Holly water & 10 & 8.33 \\
\hline Washing with water and soap & 9 & 7.5 \\
\hline Do nothing & 3 & 2.5 \\
\hline Post-exposure prophylaxis & & \\
\hline Yes & 33 & 27.5 \\
\hline No & 58 & 48.33 \\
\hline I don't know & 29 & 24.17 \\
\hline Vaccine campaign for a dog in your area & & \\
\hline Yes & 25 & 20.83 \\
\hline No & 95 & 79.17 \\
\hline Availability of vaccine & & \\
\hline Yes always & 15 & 12.5 \\
\hline Sometimes & 61 & 50.83 \\
\hline No & 44 & 36.67 \\
\hline Dog management practice & & \\
\hline let free & 73 & 60.83 \\
\hline keep indoor & 47 & 39.17 \\
\hline Your dog can bite you & & \\
\hline Yes & 76 & 63.33 \\
\hline No & 44 & 36.67 \\
\hline When a rabid dog licks your open wound, you can get rabies & & \\
\hline Yes & 78 & 65 \\
\hline No & 42 & 35 \\
\hline Do you feed your dog & & \\
\hline Once & 54 & 26.67 \\
\hline Twice & 32 & 28.3 \\
\hline Thrice daily & 34 & 100 \\
\hline Total & 120 & \\
\hline & & \\
\hline
\end{tabular}


Assessment of Community Knowledge, Attitude and Practice towards Rabies in Mersa Town, Amhara Regional State, Ethiopia

Table4. Association of Attitude and practice of the Respondents with Educational level

\begin{tabular}{|c|c|c|c|c|c|c|c|c|}
\hline Variable & Category & Illiterate & Informal & \begin{tabular}{|c|} 
Primary \\
School \\
\end{tabular} & \begin{tabular}{|c|}
$\begin{array}{c}\text { Secondary } \\
\text { School }\end{array}$ \\
\end{tabular} & $\begin{array}{c}\text { Higher } \\
\text { Education }\end{array}$ & \begin{tabular}{|c|}
$\begin{array}{c}\text { Chi }\left(\mathbf{X}^{2}\right) \\
\text { square }\end{array}$ \\
\end{tabular} & $\begin{array}{c}\text { P- } \\
\text { value }\end{array}$ \\
\hline \multirow{3}{*}{$\begin{array}{l}\text { Action for } \\
\text { rabid animal }\end{array}$} & Tie & $22(57.89)$ & $11(47.83)$ & $12(48.00)$ & $5(35.71)$ & $3(15.00)$ & \multirow[t]{3}{*}{20.8480} & \multirow[t]{3}{*}{0.008} \\
\hline & Killing & $16(42.11)$ & $9(39.13)$ & $12(48.0)$ & $8(64.29)$ & $17(85.0)$ & & \\
\hline & Do nothing & 0 & $3(13.04)$ & $1(4.00)$ & 0 & 0 & & \\
\hline \multirow{5}{*}{$\begin{array}{l}\text { Immediate } \\
\text { action taken for } \\
\text { bitten man by } \\
\text { rabid animal }\end{array}$} & $\begin{array}{l}\text { Visit health } \\
\text { center }\end{array}$ & $13(34.21)$ & $7(30.43)$ & $14(56.00)$ & $8(57.14)$ & $14(70.00)$ & \multirow[t]{5}{*}{26.4728} & \multirow[t]{5}{*}{0.048} \\
\hline & $\begin{array}{l}\text { Apply herbal } \\
\text { extract }\end{array}$ & $16(42.11)$ & $14(60.87)$ & $6(24.00)$ & $4(28.57)$ & $2(10.00)$ & & \\
\hline & Holly water & $6(15.79)$ & $1(4.35)$ & $1(4.00)$ & $2(14.29)$ & 0 & & \\
\hline & $\begin{array}{l}\text { Washing } \\
\text { with water } \\
\text { and soap }\end{array}$ & $2(5.26)$ & $1(4.35)$ & $3(12.00)$ & 0 & $3(15.00)$ & & \\
\hline & Do nothing & $1(2.63)$ & 0 & $1(4.00)$ & 0 & $1(5.00)$ & & \\
\hline \multirow{3}{*}{$\begin{array}{l}\text { Post exposure } \\
\text { prophylaxis }\end{array}$} & Yes & $10(26.32)$ & $3(13.04)$ & $7(28.00)$ & $3(21.43)$ & $10(50.00)$ & \multirow[t]{3}{*}{12.4700} & \multirow[t]{3}{*}{0.131} \\
\hline & No & $15(39.47)$ & $13(56.52)$ & $15(60.00)$ & $8(57.14)$ & $7(35.00)$ & & \\
\hline & I don't know & $13(34.21)$ & $7(30.43)$ & $3(12.00)$ & $3(21.43)$ & $3(15.00)$ & & \\
\hline \multirow{3}{*}{$\begin{array}{l}\text { Availability of } \\
\text { vaccine }\end{array}$} & Yes always & $2(5.26)$ & $4(17.39)$ & $2(8.33)$ & $3(21.43)$ & $3(15.79)$ & \multirow[t]{3}{*}{5.4161} & \multirow[t]{3}{*}{0.712} \\
\hline & Sometimes & $20(52.63)$ & $11(47.83)$ & $13(54.17)$ & $8(57.14)$ & $8(42.11)$ & & \\
\hline & No & $16(42.11)$ & $8(34.78)$ & $9(37.50)$ & $3(21.43)$ & $8(42.11)$ & & \\
\hline \multirow{2}{*}{$\begin{array}{l}\text { Dog } \\
\text { management } \\
\text { practice }\end{array}$} & Let free & $26(68.42)$ & $12(31.58)$ & $16(64.00)$ & $9(64.29)$ & $10(50.00)$ & \multirow[t]{2}{*}{2.8025} & \multirow[t]{2}{*}{0.591} \\
\hline & Keep in door & $12(31.58)$ & $11(47.83)$ & $9(36.00)$ & $5(35.71)$ & $10(50.00)$ & & \\
\hline \multirow{2}{*}{\multicolumn{2}{|c|}{ 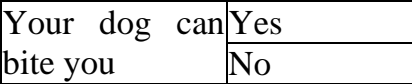 }} & $22(57.89)$ & $14(60.87)$ & $15(60.00)$ & $12(85.71)$ & $13(65.00)$ & \multirow[t]{2}{*}{3.7075} & \multirow[t]{2}{*}{0.447} \\
\hline & & $16(42.11)$ & $9(39.13)$ & $10(40.00)$ & $2(14.29)$ & $7(35.00)$ & & \\
\hline \multirow{2}{*}{\multicolumn{2}{|c|}{ 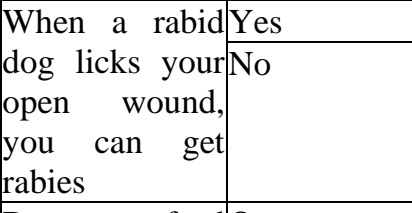 }} & $18(47.37)$ & $15(65.22)$ & $15(60.00)$ & $13(92.86)$ & $17(85.00)$ & \multirow[t]{2}{*}{13.7598} & \multirow[t]{2}{*}{0.008} \\
\hline & & $20(52.63)$ & $8(34.78)$ & $10(40.00)$ & $1(7.14)$ & $3(15.00)$ & & \\
\hline \multirow{3}{*}{\begin{tabular}{|lrr} 
Do & you & feed \\
your & dog &
\end{tabular}} & Once & $22(57.89)$ & $16(69.57)$ & $10(40.00)$ & $2(14.29)$ & $4(20.00)$ & \multirow[t]{3}{*}{21.6818} & \multirow[t]{3}{*}{0.868} \\
\hline & Twice & $7(18.42)$ & $3(13.04)$ & $10(40.00)$ & $5(35.71)$ & $7(35.00)$ & & \\
\hline & Thrice daily & $9(23.68)$ & $4(17.39)$ & $5(20.00)$ & $7(50.00)$ & $9(45.00)$ & & \\
\hline
\end{tabular}

\section{DISCUSSION}

Although the majority of respondents had heard about rabies and were aware of its transmission through dog bites, they lacked knowledge regarding certain practices and risk factors. Very few respondents knew that rabies could be transmitted by species other than domestic dogs. This is consistent with findings from a survey in Thailand that found that only $16 \%$ of participants knew that all mammals can suffer from rabies (Kongkaew et al., 2004).

This study showed that the majority of respondents (83.33\%) hand not heard about rabies. In contrary to the present study; (Ali et al., 2013) reported that $83 \%$ of the respondents had heard about rabies from different sources in Addis Ababa, Ethiopia. This difference probably is explained by the lack of media coverage and community education about rabies in the study area.

The present study revealed that $(35.3 \%)$ of the respondents described starvation and thirst as causes of the rabies disease. This finding is supported by (Ali et al., 2013) who reported 39 (39.0\%) respondents did not have any knowledge regarding the mode of transmission. On the other hand, current finding $30 \%$ of respondents who know the disease mentioned bite and Saliva as a means of transmission. This result is lower as compared to (Serebe et al., 2014) reported that $46.8 \%$ and $45 \%$. The possible reason for this could be due to the lack of the availability information gained by media about rabies transmission.

In this study, a critical component of immediate action taken for bitten man by a rabid animal is immediate washing of the bite wound with water and soap was replied by higher education level respondents (15\%) before hospital presentation. This result is evidenced by (World Health Organization, 2005). The current results showed that most of illiterate respondents were unaware of 
this preventive practice, which is consistent with other studies (Ichhpujani et al., 2008; Chhabra et al., 2004). Lack of wound washing is responsible for a five-fold increase in the risk of developing rabies (Hampson, 2008). Improved awareness of wound management (especially prompt flushing with any liquid available) could, therefore, have considerable impacts on reducing the probability of developing rabies in these communities. Washing of rabies-infected wounds with soap and water can increase survival by $50 \%$ (Pieracci et al., 2016; Radostits et al., 2007).

This study revealed that the $(52.5 \%)$ of the Respondents knew the disease can be prevented by vaccination. This finding is lower than studied done by (Chandan and Kotrabasappa, 2016); (Meltzer and Rupprecht, 1998) and (Raymond et al., 2015) who reported 67\% and 60 to $70 \%$ about rabies vaccination respectively. This difference could be associated with educational status and awareness level of the community.

In the present study, $(60.83 \%)$ of respondents were managing their dogs by kept let free. This result is evidenced by (Butler and Bingham, 2000)found which is a significant number of households in SubSaharan Africa were less likely to confine their dogs, whether in urban and rural areas. In the current study, 27.5\% of respondents for those peoples exposed to rabies used post-exposure vaccination. In contrast, the study in Bahar Dar town reported a 55.7\% response for immediate post-exposure vaccination (Guadu et al., 2014). This difference may be due to a lack of information about the importance of vaccines and the inaccessibility of vaccination service.

In the present study, $46.67 \%$ of interviewers sought traditional methods of treatment which employs the use of herbs for immediate action for bitten man by a rabid animal. Similarly, studies conducted in Gondar district, Ethiopia, reported about $62.2 \%$ of the study participants had strong beliefs in traditional medicine (Digafe et al., 2015).

In this study, higher education level was significantly associated with action for the rabid animal by a high score in killing and immediate visit health center after bitten by a rabid animal with the Chi (X2) square and P-value of $(\mathrm{x} 2=20.8480, \mathrm{p}<0.008)$ and $(\mathrm{x} 2=26.4728, \mathrm{p}<0.048)$ respectively. This finding was also supported by studies conducted by (Guadu et al., 2014) in Bahir Dar, (Ali et al., 2013) in Addis Ababa and the studies conducted in Flagstaff, Arizona, USA (McCollum et al., 2012).

\section{CONCLUSION AND RECOMMENDATIONS}

Rabies is a well-known disease in the study area and is considered to be a disease of significant public health importance. The level of knowledge about the main mode of transmission of animal bite and saliva and source animal (dog) for rabies is good. However, contact with infected saliva and Consumption of rabid animal meat should also be considered as a risk. All mammals should be considered as a potential source of infection and care should be taken in handling these animals if appear sick. On the other hand, there is a lack of training about rabies and knowledge about postexposure prophylaxis. The presence of low vaccination coverage was also well indicated. Such type of activities poses a health hazard and makes difficult the control of rabies in the area. However, control of the disease can be best achieved with a combination of vaccination, killing of stray dogs and training of community. In conclusion, regular intervention targeted at controlling stray dogs and vaccination of dogs should be employed to control the disease. Moreover, proper post-exposure treatment should be performed for human victims. Creating awareness to the community through training and public education should be implemented.

\section{REFERENCES}

[1] Ali, A., Ahmed, E. Y., and Sifer, D. (2013). A study on knowledge, attitude and practice of rabies among residents in Addis Ababa, Ethiopia. Ethiopian Veterinary Journal 17, 19-35.

[2] Butler, J., and Bingham, J. (2000). Demography and dog-human relationships of the dog population in Zimbabwean communal lands. Veterinary Record 147, 442-446.

[3] Chandan, N., and Kotrabasappa, K. (2016). Awareness of animal bite and rabies among agricultural workers in rural Dharwad, Karnataka, India. International Journal of Community Medicine and Public Health 3, 1851-1855.

[4] Digafe, R. T., Kifelew, L. G., and Mechesso, A. F. (2015). Knowledge, attitudes and practices towards rabies: questionnaire survey in rural household heads of Gondar Zuria District, Ethiopia. BMC research notes 8, 400.

[5] Guadu, T., Shite, A., Chanie, M., Bogale, B., and Fentahun, T. (2014). Assessment of knowledge, attitude and practices about rabies and associated factors: in the case of Bahir Dar town. Global Veterinaria 13, 348-54. 
[6] Kang, B., Oh, J., Lee, C., Park, B.-K., Park, Y., Hong, K., Lee, K., Cho, B., and Song, D. (2007). Evaluation of a rapid immunodiagnostic test kit for rabies virus. Journal of virological methods 145, 30-36.

[7] Kloos, H., and Berhane, Y. (2006). Zoonotic diseases of public health importance. Epidemiology and Ecology of Health and Diseases in Ethiopia. 1st edition. Edited by: Berhane Y, Hailemariam D, Kloos H. Addis Ababa: Shama books, 692-700.

[8] Knobel, D. L., Cleaveland, S., Coleman, P. G., Fèvre, E. M., Meltzer, M. I., Miranda, M. E. G., Shaw, A., Zinsstag, J., and Meslin, F.-X. (2005). Re-evaluating the burden of rabies in Africa and Asia. Bulletin of the World health Organization 83, 360-368.

[9] Kongkaew, W., Coleman, P., Pfeiffer, D. U., Antarasena, C., and Thiptara, A. (2004). Vaccination coverage and epidemiological parameters of the owned-dog population in Thungsong District, Thailand. Preventive veterinary medicine $65,105-115$.

[10] LFOM (2013). Livestock and Fishery Office of Mersa. North Wollo.

[11]Lozano, R., Naghavi, M., Foreman, K., Lim, S., Shibuya, K., Aboyans, V., Abraham, J., Adair, T., Aggarwal, R., and Ahn, S. Y. (2012). Global and regional mortality from 235 causes of death for 20 age groups in 1990 and 2010: a systematic analysis for the Global Burden of Disease Study 2010. The lancet 380, 2095-2128.

[12] McCollum, A. M., Blanton, J. D., Holman, R. C., Callinan, L. S., Baty, S., Phillips, R., Callahan, M., Levy, C., Komatsu, K., and Sunenshine, R. (2012). Community survey after rabies outbreaks, Flagstaff, Arizona, USA. Emerging infectious diseases 18, 932.

[13] Meltzer, M. I., and Rupprecht, C. E. (1998). A review of the economics of the prevention and control of rabies. Pharmacoeconomics 14, 365-383.

[14]Pieracci, E. G., Hall, A. J., Gharpure, R., Haile, A., Walelign, E., Deressa, A., Bahiru, G., Kibebe, M., Walke, H., and Belay, E. (2016). Prioritizing zoonotic diseases in Ethiopia using a one health approach. One Health 2, 131-135.

[15] Radostits, O. M., Gay, C., Hinchcliff, K. W., and Constable, P. D. (2007). A textbook of the diseases of cattle, horses, sheep, pigs and goats. Veterinary medicine 10, 2045-2050.

[16] Raymond, T. N., Roland, M. E., Françoise, K. M., Francis, Z., Livo, E. F., and Clovis, S. T. (2015). Do open garbage dumps play a role in canine rabies transmission in Biyem-Assi health district in Cameroon? Infection ecology \& epidemiology 5, 26055.

[17] Serebe, S. G., Tadesse, K. A., Yizengaw, H. A., and Tamrat, S. M. (2014). Study on community knowledge, attitude and practice of rabies in and nearby Gondar town, North West Ethiopia. Journal of Public and Epidemiology 6, 429-35.

[18] World Health Organization (2005). The control of neglected zoonotic diseases: a route to poverty alleviation Report of a Joint WHO/DFID-AHP Meeting with the participation of FAO and OIE. Geneva, Switzerland: WHO.

[19] World Health Organization (2014). WHO'S first global report on antibiotic resistance reveals serious, worldwide threat to public health. Antimicrobial resistance-global surveillance report. In "Virtual Press Conference", Vol. 30, pp. 253-65.

[20] Yimer, E., Mesfin, A., Beyene, M., Bekele, A., Taye, G., Zewdie, B., and Alemayehu, T. (2012). Study on knowledge, attitude and dog ownership patterns related to rabies prevention and control in Addis Ababa, Ethiopia. Ethiopian Veterinary Journal 16, 27-39.

[21]Zewdie, W., Wario, E., and Tehetna, A. (2018). Assessment of Community Awareness on Common Zoonotic Disease in and around Yabello District of Oromia Regional State, Ethiopia. Multidisciplinary Advances in Veterinary Science 2, 388-394.

Citation: Haben Fesseha, et.al (2020). "Assessment of Community Knowledge, Attitude and Practice towards Rabies in Mersa Town, Amhara Regional State, Ethiopia". International Journal of Research Studies in Microbiology and Biotechnology (IJRSMB), vol. 6, no. 2, pp. 6-13, 2020. Available: DOI: http://dx.doi.org/ 10.20431/2454-9428.0602003

Copyright: (C) 2020 Authors. This is an open-access article distributed under the terms of the Creative Commons Attribution License, which permits unrestricted use, distribution, and reproduction in any medium, provided the original author and source are credited. 